bilities for working and realisation. It may turn out eventually as a good place for investment of capital, and I hope may. But this puffing is altogether much too premature. The commencement of Australia and California was very different. The actual nuggets turned up honestly, and spoke for themselves.

\title{
INOTICES OF IMFMOIRS.
}

\section{I.-On a Remarkablu Incrustation in Northamptonshire.}

By SaMUri Searp, F.S.A., F.G.S. ${ }^{1}$

A SPECIMEN of a plant incrusted by carbonate of lime having $A$ been left at the Northampton Museum (of the Geological Department of which I am the Hon. Curator), I visited the place whence it had been brought-an ancient gravel-pit about three miles from the village of old or Wold, and some fourteen miles N.N.E. of Northampton.

The section exposed is about eight feet in height, and the gravel contains broken flints, angular and sub-angular fragments from the Oolitic limestone and ironstone of the district, and rounded pebbles, composed for the most part of materials foreign to the locality, and derived from older gravels or from the Boulder-clay which caps many of the high lands in the county.

In the section of the gravel, I found the mass of incrusted plants from which the small fragment had been taken. This, as seen in the section, is about ten feet in length, and about two feet six inches in thickness (see Woodcut). Its dimensions inwards were

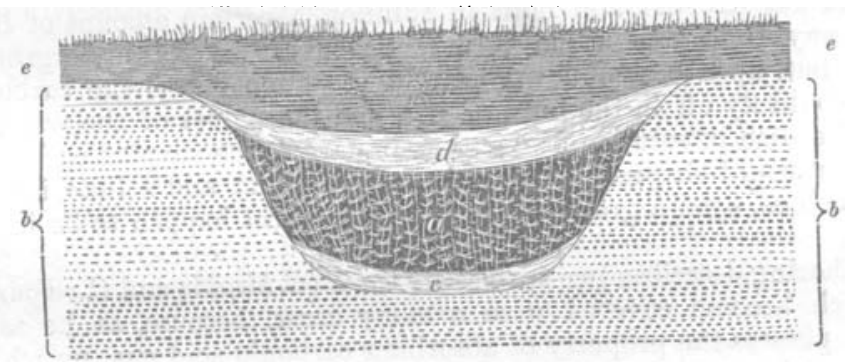

Diagram-section of side of Gravel-pit near Old, Northamptonshire, showing position of ancient tufaceous deposit containing Chara vulgaris.

a. Mass of incrusted Chara vulgaris ( 21 feet in thickness, and 10 feet in breadth.)

b. Stratified gravel ( 8 feet in thickness).

c. Lower layer of calcareous paste (6 inches in thickness).

d. Upper layer of calcareous paste ( 12 inches in thickness).

c. Surface soil ( 9 inches, deepening to $I$ foot 9 inches).

not ascertainable, and no trace of it was to be found in the opposite section of the pit, distant some fifteen or twenty feet. It reposes upon six inches of calcareous paste, made up of the decomposed material of the mass, and this paste again rests upon the gravel as a base.

1 Read before the British Association, Section C. Norwich, August, 1868. 
A similar layer of calcareous paste, one foot in thickness, overlies the mass, and has partially filled the interstices of the incrusted plant. The whole is covered in with surface soil of the thickness of one foot nine inches, the depth of the general surface soil overlying the gravel being only nine inches, but the surface level being the same.

The gravel is stratified, showing that it has remained undisturbed since it was originally deposited, and the strata run up to the mass of incrustation on either side, abutting sharply upon it, and were evidently once continuous.

These are the simple facts which I ascertained upon examination of the mass of incrustation in situ, and upon observation of the surrounding circumstances; and I may, perhaps, be permitted to suggest briefly what may have been the history of its formation.

Ages before the ground was first broken to make the present gravel pit-at a period perhaps as remote as that when savage man roamed over the country, an excavation was made at this spot (probably to obtain water) and a pool was formed, about ten feet across, and about five feet deep, in which grew luxuriantly a water plant, which Mr. Carruthers, F.L.S., F.G.S., of the British Museum, has kindly informed me was the Chara vulgaris of Linnæus.

Rain, upon falling on the surface, soaks through the soil, and percolating the porous rock beneath, descends by its own gravity until stopped by the occurrence of a clay or other impervious bed : it then accumulates and travels until it finds vent at favourable points of the surface, and issues thence in the form of springs.

It is not an uncommon thing for water, charged with carbonic acid, to dissolve out and hold in solution a certain amount of lime from any limestone which it may encounter in its underground flow ; but, upon becoming exposed to the atmosphere, the carbonic acid would $\mathrm{fly}$ off in the form of gas, and the power of the water to hold the lime in solution being thus impaired, the surplus carbonate of lime would be precipitated, and collect round and solidly incrust any nucleus, even a growing plant, which might happen to be in the water.

Withering describes two species of Chara (C.hispida and C. vulgaris) - which become covered with a stony crust, because, as he says, " they possess the property of absorbing carbonic acid gas, by which lime has been held in solution, in a greater degree than any other water-plant;" and this would enhance the tendency in the water in which such plants might grow to deposit lime, so far as regards the incrustation of those plants.

The gravel contains many fragments of the limestone of the district; and $I$ found in it pieces which apparently had been exposed to the dissolving agency described.

The Chara, then in its rich and matted growth, in the pool of water thus impregnated with lime, became incrusted-first at the bottom, and gradually upwards-as the plant, still accumulating in its growth, approached nearer and nearer to the surface.

By this slow process of growth and incrustation, the pool, in the 
course of time, was choked up, becoming at length only a shallow puddle. The six inches of calcareous paste at the bottom was probably produced by the crushing of the lower portion of the incrustation by the superincumbent weight; and the thick layer at top, partly by atmospheric disintegration, and partly, perhaps, by the trampling of cattle while drinking. The pool ultimately became a mere marshy hollow, and was then artificially filled in with soil to the level of the surrounding surface. The gravel-pit was subsequently opened, and what had been the hollow of the pool was thus thoroughly drained.

The incrustation lies in layers, the plant stems being in a greatly inclined position. I would suggest that this may, perhaps, be attributable to the deciduousness of the plant, or to the variation in the water-level arising from the change of seasons.

There is one peculiarity which I must notice. The gravel-pit is situated on the slope of a rather shallow valley, through which flows the brook I have referred to. The bottom of the pit is some feet above the level of the water of that brook, and about three feet below the bottom of the supposed former pool : at a time of the year when water should have been present, if at all, the pit was perfectly dry. It is clear, then, that the old local conditions must have been very different to the present, to have rendered it possible for water to accumulate in an excavation in that open gravel to such an extent as to allow of the Chara growing in luxuriance to within a foot of the surface. It would really seem that, in the long interval which has elapsed since the growth and incrustation of that mass of plant, a change must have taken place in the level of the locality, and that the valley itself must have been excavated to a greater depth. If this view be sound, and the pool or hollow be really the work of man's hands, we have here another item of evidence of the high antiquity of the human race. ${ }^{1}$

There is yet another consideration. Had the gravel pit not been opened, the calcareous paste of the upper bed would, by percolation, in the course of time, have completely filled up the interstices of the mass of incrusted plant, and ultimately the whole might have become hardened into a marly limestone rock. If excavation should then have occurred, what would have been the reasonable conclusion as to the nature and origin of the apparently calcareous mass? Would it not have been that, occurring in the stratified gravel, it was a transported block, and its presence in such a position attributable to Glacial agency ?

1 Mr. George Maw, F.G.S., etc., upon the facts as detailed by the writer of the paper, has expressed an opinion (qualified by the consideration that he has not examined the place) that the hollow was the work of human ageney.

2 The valley is cut through the lower beds of the ferruginous sandstone of the district; upon the slope so formed the gravel was deposited, and the ferruginous sandstone reposes upon the upper lias clay. Neither of these beds contain sufficient calcareous matter to allow of any subsidence arising from the dissolving out and carrying away (by the action of water charged with carbonic acid in solution), of any considerable portion of their mass. 


\title{
II.-On the Tertiaky Difostte of Viotoria.
}

\author{
By H. M. JENKnng, F.G.S.1
}

THEE geology of Victoria is better known than that of any other 1 British colony, the existence of gold-bearing deposits in different localities having led to the establishment of a Government Geological Survey about twelve years ago. The labours of this survey, under the able direction of Mr. Selwyn, have made known to us, in a general way, the geological structure of the whole colony, and a more detailed survey is now in active progress.

The marked contrast to our knowledge of the geological features of Victoria is our comparative ignorance of its palæontology.

Under these cireumstances Mr. Selwyn has sent the author for determination a large series of Tertiary fossils from the beds which he has mapped as Miocene and older Pliocene; and as they present some points of very great interest to the palæontologist, he gave an account of the localities whence they had been obtained, as a preface to a report on the fossils, which he hoped to lay before the Association on a future occasion.

One point of great importance, depending on the correct interpretation of the age of these Tertiary strata, is the date of the payable gold-drifts of Victoria. Their age relatively to other deposits has been tolerably well made out by Mr. Selwyn; but, as a matter of scientific interest, their antiquity in relation to changes in the climate, and in the fauna and flora of the region, has still to be determined.

The most varied section of the marine Tertiary beds of Victoria is exhibited on the coast west of Cape Otway, a headland situated southwest of Port Philip Bay, where the Tertiary deposits were accumulated in a trough of Mesozoic carbonaceous sandstone between Castle Cove and Cape Otway; and the Tertiary beds were afterwards contorted and then denuded; and the trough, now deeper and probably narrower, was refilled with the Post-pliocene false-bedded sandstone.

It is of great importance to determine the relations of these beds, as one of them has yielded the Trigonia semiundulata (M'Coy), a shell of Secondary type, quite different from the recent species, and more comparable with the $T$. costata of the Oolites.

About twenty miles west of Castle Cove, and nearly five miles beyond Moonlight Head, another series of Tertiary deposits occurs, resting, as before, on the Mesozoic sandstone.

West of the Gellibrand river the Miocene beds rise from beneath Post-pliocene calcareous sandstone, dipping to the eastward ; that is, in the opposite direction to those on the other side of the river's mouth. They extend along the coast for nearly forty miles, but their stratification and divisions are much obscured by the fallen masses of the more recent Tertiary sandstone. The most important bed is a dark, slate-coloured, stiff clay, very rich in fossils, and

1 Read before the British Association (Section C.) Norwich, August, 1868. 


\section{Jenkins-Geology of Victoria.}

remarkable for yielding, perhaps, the finext examples of Cyproa which occur in the fossil state. The fossils from this bed present a very striking contrast to those from the eastern side of the River Gellibrand in the perfection of their preservation.

The author then described some small sections still further west, and afterwards the strata on the western side of Port Philip Bay, at Fyansford, about four miles west of Geelong, whence fossils have been obtained from a section exposed in the cliff on the right bank of the river Barwon.

A little west of Geelong, and close to the shore, the cliffs exhibit Miocene strata, which have been correlated by the geological surveyors with the upper part of the Spring Creek series, further to the south, where a very extensive succession of beds has been made out, extending from the mouth of Spring Creek to the Bird Rock, and presenting a total thickness of about 280 feet.

On the eastern shore of Port Philip Bay the series is even more diversified. It is also of pecnliar interest, as Professor M'Coy regards certain of the strata on this side, near Mount Eliza, at Schnapper Point, as belonging to the upper Eocene period; but it is extremely difficult to decide what characters would entitle an Australian deposit to be regarded as Eocene. Nummulites have not yet come under the author's observation, and the shells appear to have too recent a facies for an Eocene fauna, although some of the volutes do recall the species of our Bracklesham beds, and those of the German Oligocene deposits.

Mordialloc, about fifteen miles north of Schnapper Point, is of interest on account of a boring for an Artesian well having been sunk there to a depth of 240 feet, the basalt which underlies the strata of that district having been struck at a depth of 235 feet. From the sandstone cliff north of Mordialloc, fossils have been obtained which, though badly preserved, are evidently of more recent date than those from the beds near Mount Eliza; indeed they are mapped as Lower Pliocene by the Geological Survey of Vietoria. The beds exposed do not exceed 18 feet in thickness.

The fossils from these various deposits yield nothing either in numbers or in beauty of preservation to those of the London or Paris basins; but until they have been carefully worked out, and their affinities properly determined, it is extremely hazardous to venture on any opinion as to the age of the strata from which they have been obtained. That there are several horizons is at once evident, and that some of the assemblages of fossils from different localities are contemporaneous is extremely probable. For instance, the deposit near the Sherbrook river, which has yielded the Trigonia of recent type (T. Lamarckii), is probably referable to the same horizon as the Mordialloc deposits, which are characterised by the same form of Trigonia, and which have been mapped by the geological surveyors as Lower Pliocene. 


\section{III.-On the Fossix Fishes of the Dudhy of Cornwate.}

By C. W. Peach, A.L.S.

$T^{\mathrm{N}}$ 1841, at the meeting at Plymouth, I read a paper on the above subject, and stated that I had found "portions of fishes at Punch's Cross Quarry near Fowey." Again at Cork in 1843, I continued the subject, having met with far better specimens, and still finer had been found by Mr. Couch, at Polperro; these latter with some of my own were there exhibited and commented on by me.From that time to 1849 , I continued to extend my researches, and met with fish-remains on both sides of the county. All these, I felt satisfied, were portions of fishes, and in this opinion I was supported by several eminent naturalists, especially by the late valued Professor E. Forbes, Mr. Pengelly, and others. In 1849 I left Cornwall for Scotland, and have not again been there.

These things were considered fishes until 1855, when Professor M'Coy (who had been some time before round Cornwall with Professor Sedgwick) stated in the "British Palæozoic Fossils," published at Cambridge, after carefully examining some of the original specimens, and others that he had collected, that they were not Fishes, but Sponges, of which he made out two species. So they have been considered up to April of the present year, when Mr. E. Wyatt-Edgell, in the Geological Magazine, for May, said, that the so-called Steganodictyum (Sponges) of M'Coy were true Fish-remains; and in this he is supported by Professor Huxley, Messrs. E. Ray Lankester, Salter, and Woodward. I confess to feeling pleased at knowing, that, although these interesting remains have been so long under a cloud, light has at last broken upon them, and that their true history will soon be told. Although I have bowed silently to authority so long, my opinion as to their fish character has never changed; and in all my wanderings over the Old Red Sandstone of Caithness, and other parts of Scotland,-with one exception, to be mentioned bye and bye, - the only thing in all the fishes I met with, and these may be told by hundreds, I never found one which agreed with the Cornish ones; however, a few decayed bones of Osteolepis, etc., showed the same cancellated structure as the specimens from the Cornish rocks. In May last I went on a visit to my son, who is in the Geological Survey, at Lesmahagow, and amongst the Blackband Ironstone, in one of the coalpits at Auchenheath, I got fish-remains showing identically the same net-work cancellated structure. This peculiar structure deceived morethan Professor M Coy. Many named it to me when talking about the Cornish fishes, because "it differed so widely from that of any known animal structure: " consequently they refused to believe them fishes. Here let me do justice to Professor $M^{\circ} \mathrm{Coy}$. He did not see the specimens on which I formed my opinion : they were with me in Scotland, and were not sent to the Geological Museum at Penzance until long after he had given his decision. The exception above mentioned is a small tuberculated piece, one of

1 Read before the British Association (Section C.) Norwich, August, 1868. 
those sent to the Cornish Museum, and figured by me in the Geological Transactions of Cornwall, for 1848, at Pl. iii. Fig. 2 : it is so much like the outer part of an Asterolepis, or Coccosteus, that the late Hugh Miller, on seeing it, said, "had he found it in Caithness or Cromarty, he should without hesitation have considered it as belonging to one of those fishes." Strong testimony this. I have lately seen the paper of Mr. E. Ray Lankester, in Vol. xxi. of the Palæontological Society, and by the figures and descriptions there given, I am the more convinced of the Piscine nature of the Cornish fossils, and farther, that they will prove to belong to some of the families described there. The Cornish ones are very much larger, and consequently may prove new species. Roused by the new state of affairs, I have turned out the contents of a box, packed twenty years ago on leaving Cornwall, and up to that time untouched. Here I found a splendid cephalic shield. It is a little more than six inches in length, unfortunately not perfect. I have as well some nice but fragmentary specimens of scales and spines, all beautifully markedthese are merely a few odds and ends left after my collection was placed in the Geological Museum at Penzance. If these specimens were examined carefully, they would be found to throw a great deal of light on the subject, especially the spines. I greatly regret that I cannot go there to do it myself.

\section{REVIFWS.}

I.-Prinotpless of Geologi; or, the Modern Changes of the Earth aNd itg Inhabitants considgred as Illugstrative of Grologr. By Sir Charles Lyell, Bart., M.A., F.R.S. 10th and entirely revised edition. In two volumes. Vol. II. Illustrated with Maps, Plates, and Woodcuts. 8vo. pp. 649. London: John Murray. 1868.

TN the Grologidal MaGazine for 1867, Vol. IV. p. 120, we gave a 1 brief notice of the new edition of the first volume of this grand work.

Great and important as had been the alterations in Volume I., we cannot but think that the second volume is by far the most valuable, both as to its matter and the treatment it has received from the author.

The following account of some of the prineipal additions to this volume will enable the reader to see how much labour has been bestowed upon the new edition. Much new information has been added to the chapter on Mount Etna, in consequence of the author's re-examination of this volcano in 1857 and 1858. The theory of a double axis of eruption is explained (p. 9), and the changes in the scenery of the Val del Bove, caused by the lavas of 1852, are described (p. 31). The solid texture and steep original inclination of certain lavas of known date are also pointed out ( $p$ p. 35 and 36), and the relation of some ancient valleys on Etna to the former structure of the mountain is considered (p. 40).

An account is given (at p. 69) of the changes produced by the

VOL. V.-NO. LIV. 